\title{
Effects of different algae in diet on growth and interleukin (IL)-10 production of juvenile sea cucumber Apostichopus japonicus
}

\author{
Md Anisuzzaman ${ }^{1}$, Jeong U-Cheol' ${ }^{1}$ Jin Feng ${ }^{1}$, Choi Jong-Kuk', Kabery Kamrunnahar ${ }^{1}$, Lee Da-In², Yu Hak Sun ${ }^{2}$ \\ and Kang Seok-Joong ${ }^{1 *}$
}

\begin{abstract}
The experiment was conducted to investigate the effects of different algae in diet on growth, survival, and interleukin-10 productions of sea cucumber. At first, a 9-week feeding trail was conducted to evaluate the growth performance and survival of the sea cucumber fed one of the six experimental diets containing ST (Sargassum thunbergii), UL (Ulva lactuca), UP (Undaria pinnatifida), $\sqcup$ (Laminaria japonica), SS (Schizochytrium sp.), and NO (Nannochloropsis oculata) in a recirculating aquaculture system. The result showed that survival was not significantly different among the dietary treatments, and the specific growth rate (SGR) of sea cucumber fed the UL diet $\left(1.58 \% \mathrm{~d}^{-1}\right)$ was significantly higher than that of sea cucumber fed the other diets $(P<0.05)$, except for the $L$ and NO diets. Secondly, interleukin (IL)-10 gene expression was determined where mice splenocytes were stimulated with $10 \mathrm{\mu g} \mathrm{ml}^{-1}$ of sea cucumber extracts for $2 \mathrm{~h}$. The result showed that IL-10 gene expression levels were significantly increased in UL, $L$, and NO diets fed sea cucumber extracts compared to other experimental diets. The results suggest that dietary inclusion with Ulva lactuca, Laminaria japonica, and Nannochloropsis oculata algae may improve the growth of juvenile sea cucumber and could upregulate IL-10 gene expression in mice splenocytes. Such detailed information could be helpful in further development of more appropriate diets for sea cucumber culture.
\end{abstract}

Keywords: Sea cucumber (Apostichopus japonicus), Algae, Growth, Interleukin (IL)-10

\section{Background}

The sea cucumber, Apostichopus japonicus, has become an important mariculture species in Russia, China, Japan, and South Korea because of its relatively high economic value (Sloan 1984). Market demand for this species increased because of its aphrodisiac and curative properties (Liao 1997). However, the production of sea cucumbers obtained from the natural environment has declined due to overexploitation and pollution (Conand 2004). Depletion of wild production together with high commercial value has encouraged the people to develop aquaculture methods for holothurians, especially $A$. japonicus (Conand 2004; Yuan et al. 2006).

\footnotetext{
*Correspondence: sjkang@gnu.ac.kr

${ }^{1}$ Department of Seafood and Aquaculture Science, Gyeongsang National University, Tongyeong 53064, Republic of Korea

Full list of author information is available at the end of the article
}

Successful culture of juvenile sea cucumbers requires proper knowledge about feed intake behavior and dietary requirements (Slater et al. 2009). However, little is known regarding which artificial diets are capable of inducing rapid growth and healthy conditions of commercially important sea cucumbers (Slater et al. 2009; Yuan et al. 2006; Zhou et al. 2006).

Sea cucumbers are deposit feeders that ingest sediment containing organic matter, including bacteria, protozoa, diatoms, and detritus of plants or animals (Yingst 1976; Moriarty 1982; Zhang et al. 1995; Feng et al. 2016a, 2016b). A. japonicus preferentially inhabits the sea bottom in flourishing large algae, rich detritus of which provide sea cucumber with its main organic nutrient ( $\mathrm{Li}$ et al. 1994; Zhang et al. 1995). Traditionally, sea cucumbers are cultured in earthen ponds without artificial feed. But recently, farmers have started to feed the sea 
cucumbers with formulated diets to increase production (Shi et al. 2013). Formulated diets for sea cucumbers are commonly made of macroalgal powder and sea mud. Among macroalgae, the brown algal Sargassum thunbergii is widely distributed over shallow coastal areas in Korea, Japan, and China and commonly used as a feed ingredient in sea cucumber culture (Sui 1989; Battaglene et al. 1999). However, it is difficult to satisfy demand for sea cucumber culture because this algal species is not produced commercially and its use as feed ingredients is also expensive (Lobban and Harrison 1994). In addition, more and more $S$. thunbergii have been harvested in recent years with the rapid expansion of sea cucumber farming scale, which results in severe damage to $S$. thunbergii resource (Yuan 2005; Wang et al. 2006).

Meanwhile, by feeding with commercial feed which mostly used $S$. thunbergii, sea cucumber have a high level of $\mathrm{n}-6$ fatty acids and low $\mathrm{n}-3$ fatty acids and the balance of the n-3/n-6 ratio is not good (Feng et al. 2016a, 2016b). But $n-3$ fatty acids and a good balance of the $n-3 / n-6$ ratio is very important to protect from allergic and inflammatory diseases like asthma. So, reducing the $S$. thunbergii content of sea cucumber feed will be one strategy to increase the sustainability of the sea cucumber culture.

Therefore, it is critical to find good substitutes for $S$. thunbergii to relieve the pressure on natural S. thunbergii resource and produce good quality sea cucumber. Several researchers reported that juvenile sea cucumbers fed commercially available dried powdered macroalgae (Ulva lactuca, Laminaria japonica, Sargassum thunbergii, Sargassum polycystum) and sea mud exhibited significant growth (Battaglene et al. 1999; Liu et al. 2010; Zhu et al. 2007). In our study, we used Ulva lactuca, Undaria pinnatifida, Laminaria japonica, Nannochloropsis oculata, and Schizochytrium sp. as a partial alternative source of Sargassum thunbergii to produce significant growth and good quality sea cucumber. Ulva lactuca, Undaria pinnatifida, and Laminaria japonica are popular and cheaper algae in Korea and widely used in the culture of sea urchins and abalone (Agatsuma 2000, Qi et al. 2010). Nannochloropsis oculata and Schizochytrium sp. are considered promising algae for aquaculture and offer high levels of polyunsaturated fatty acids (PUFAs), especially eicosapentaenoic acid (EPA, 20:5n-3) and docosahexaenoic acid (DHA, 22:6n-3) respectively (Kandilian et al. 2013 Yue et al. 2004).

Sea cucumbers have many therapeutic effects against various diseases (Bordbar et al. 2011; Guo et al. 2015). Moreover, sea cucumber extracts have potent biological effects and have antiviral, anticancer, antibacterial, antioxidant, and anti-inflammation effects (Esmat et al. 2013; Farshadpour et al. 2014; Kiani et al. 2014; Wijesinghe et al. 2013). In China and Malaysia, sea cucumbers have been traditionally used for the remedy of different inflammatory diseases like asthma. Asthma is a chronic inflammatory disease and a major public health problem. Interleukin (IL)-10 is a potent anti-inflammatory cytokine that downregulates the synthesis of Th1 (T helper 1)- and Th2 ( $\mathrm{T}$ helper 2)-associated cytokines, chemokines, and inflammatory enzymes. It plays a vital role for the mitigation of allergic responses. But till now, there are no reports demonstrating the effect of different algae in sea cucumber on IL-10 production.

In this study, the effects of different algae in diet on growth, survival, and anti-inflammatory cytokine (IL-10) production of the juvenile sea cucumber were examined.

\section{Methods}

\section{Experimental diets}

Six experimental diets designed as Sargassum thunbergii (ST), Ulva lactuca (UL), Undaria pinnatifida (UP), Laminaria japonica (LJ), Schizochytrium sp. (SS), and Nannochloropsis oculata (NO) were prepared. Ingredients and proximate compositions of experimental diets are presented in Table 1. Most sea cucumbers are deposit feeders that ingest sediment with organic matter. Several studies showed that juvenile sea cucumbers fed different algae and sea mud exhibited significant growth (Battaglene et al. 1999; Liu et al. 2009; Hai-Bo et al. 2015. ST diet was used as the control diet where 15\% Sargassum thunbergii and 15\% wheat flour were used. For diets UL, UP, LJ, SS, and NO, wheat flour was replaced by $15 \%$ UL, UP, LJ, SS, and NO respectively. All ingredients were ground into fine powder through a $200-\mu \mathrm{m}$ mesh, thoroughly mixed, and stored at $-20{ }^{\circ} \mathrm{C}$.

\section{Experimental animal and feeding trail}

The experiment was carried out for 9 weeks in the laboratory of Marine Biology and Aquaculture, Gyeongsang National University, Republic of Korea. Sea cucumbers used in this experiment were collected from the Goseong Sea cucumber farm. Prior to the experiment, sea cucumbers were transferred to the laboratory in fiberglass aquaria and acclimated for 2 weeks at $18{ }^{\circ} \mathrm{C}$.

After 2 days starvation, 240 sea cucumbers with initial wet body weights of $2.98 \pm 0.06 \mathrm{~g}$ (mean $\pm \mathrm{SE}$ ) were randomly selected from acclimatized sea cucumbers and placed in equal number into 24 fiberglass aquaria $\left(45 \times 60 \times 50 \mathrm{~cm}^{3}\right)$ to form six groups in tetraplicate. The six groups were fed with different experimental diets such as ST, UL, UP, LJ, SS, and NO respectively. A complete randomized block design was used to arrange the 24 aquaria of six treatment groups. 
Table 1 Ingredients and composition of experimental diets for Apostichopus japonicus (\% dry matter basis)

\begin{tabular}{|c|c|c|c|c|c|c|}
\hline Ingredients & ST (control) & UL & UP & $\sqcup$ & SS & $\mathrm{NO}$ \\
\hline Ulva lactuca powder & 0 & 15 & 0 & 0 & 0 & 0 \\
\hline Undaria pinnatifida powder & 0 & 0 & 15 & 0 & 0 & 0 \\
\hline Laminaria japonica powder & 0 & 0 & 0 & 15 & 0 & 0 \\
\hline Schizochytrium sp. powder & 0 & 0 & 0 & 0 & 15 & 0 \\
\hline Nannochloropsis oculata powder & 0 & 0 & 0 & 0 & 0 & 15 \\
\hline Wheat flour & 15 & 0 & 0 & 0 & 0 & 0 \\
\hline Seaweed powder & 15 & 15 & 15 & 15 & 15 & 15 \\
\hline Soybean meal & 8 & 8 & 8 & 8 & 8 & 8 \\
\hline Shellfish powder & 8 & 8 & 8 & 8 & 8 & 8 \\
\hline Shell powder & 2 & 2 & 2 & 2 & 2 & 2 \\
\hline Calcium phosphate & 2 & 2 & 2 & 2 & 2 & 2 \\
\hline Yeast protein & 5 & 5 & 5 & 5 & 5 & 5 \\
\hline Soyabean lecithin & 4 & 4 & 4 & 4 & 4 & 4 \\
\hline Mineral premix ${ }^{a}$ & 0.5 & 0.5 & 0.5 & 0.5 & 0.5 & 0.5 \\
\hline Vitamin premix ${ }^{b}$ & 0.5 & 0.5 & 0.5 & 0.5 & 0.5 & 0.5 \\
\hline Sea mud & 40 & 40 & 40 & 40 & 40 & 40 \\
\hline \multicolumn{7}{|l|}{ Proximate composition (\%) } \\
\hline Crude protein & 17.74 & 17.03 & 17.48 & 16.87 & 17.59 & 19.64 \\
\hline Crude lipid & 3.39 & 3.72 & 3.11 & 3.32 & 7.44 & 5.64 \\
\hline Ash & 41.20 & 44.80 & 45.55 & 45.85 & 41.5 & 42.10 \\
\hline
\end{tabular}

During the experiment, aeration was provided continuously and to ensure water quality two thirds volume of the water in each aquarium was exchanged every day. Seawater temperature was controlled at $18 \pm 1.0{ }^{\circ} \mathrm{C}$. Dissolved oxygen was maintained above $5.0-7.0 \mathrm{mg} \mathrm{l}^{-1}$, and the levels of ammonia in the water of the aquaria were less than $0.25 \mathrm{mg} \mathrm{l}^{-1}$. Other conditions were salinity $32 \pm 1 \mathrm{ppt}$, pH 7.7-8.3, and photoperiod 24-h dark.

\section{Procedure and sample collection}

Twenty-four sea cucumbers were collected as an initial sample before starting the experiment. During the experiment, sea cucumbers were fed once per day (at about 1700 hours). Uneaten feed were collected by siphon after $24 \mathrm{~h}$ and then dried at $65{ }^{\circ} \mathrm{C}$ to constant weight. Sea cucumber feces were also collected by siphon once per day (1600 hours). The feces were dried at $65{ }^{\circ} \mathrm{C}$ to constant weight, and those from each aquarium were pooled for further analysis. At the end of the 9week experiment, all the experimental sea cucumbers were deprived of food to clear their guts for 2 days, weighed, and then dried at $65{ }^{\circ} \mathrm{C}$ until constant weight was achieved.

\section{Data calculation}

Survival rate (SR), specific growth rate (SGR), ingestion rate (IR), feces production rate (FPR), and food conversion efficiency (FCE) were calculated as follows:

$$
\begin{aligned}
& \operatorname{SR}(\%)=100 \times\left(N_{2} / N_{1}\right) \\
& \operatorname{SGR}\left(\% \mathrm{~d}^{-1}\right)=100\left(\ln W_{2}-\ln W_{1}\right) / T \\
& \operatorname{IR}\left(\mathrm{g} \mathrm{g}^{-1} \mathrm{~d}^{-1}\right)=\mathrm{I} /\left[T\left(W_{2}+W_{1}\right) / 2\right] \\
& \operatorname{FPR}\left(\mathrm{g} \mathrm{g}^{-1} \mathrm{~d}^{-1}\right)=F /\left[T\left(W_{2}+W_{1}\right) / 2\right] \\
& \operatorname{FCE}(\%)=100\left(W_{2}-W_{1}\right) / I
\end{aligned}
$$

where $N_{1}$ is the number of individuals alive at start of the experiment and $N_{2}$ is the number of individuals alive at end of the experiment; $W_{1}$ and $W_{2}$ are initial and final combined dry weights, respectively, of all 10 sea cucumbers in each aquarium; $T$ is the experimental period; $I$ is the dry weight of the total feed ingested; and $F$ is the dry weight of feces.

\section{Preparation of sea cucumber extract}

At first, our experimental sea cucumbers were cleaned and the visceral organs removed. After that, the sea 
cucumbers were cut into small pieces and homogenized. One hundred fifty grams of samples were boiled in $300 \mathrm{ml}$ distilled water for $20 \mathrm{~min}$. After removing solid materials from the water, the boiled water was vaporized using a microwave until the mixture was reduced by $50 \%$. After centrifugation of the extracts at $500 \times \mathrm{g}$ for $10 \mathrm{~min}$, a fivefold volume of $100 \%$ ethyl alcohol was added to the supernatant and incubated at $20{ }^{\circ} \mathrm{C}$ for $24 \mathrm{~h}$. After that, the supernatant was discarded. The extract pellet was washed with 70\% ethyl alcohol and centrifuged under the same conditions. The supernatant was discarded, and the pellet was evaporated under a vacuum. The final extracts were prepared by re-suspending the pellet in $20 \mathrm{ml}$ distilled water (Lee et al. 2016).

\section{IL-10 gene expression}

In order to analyze the IL-10 gene expression, mice splenocytes were stimulated with $10 \mu \mathrm{g} \mathrm{ml}^{-1}$ of each experimental diet-fed sea cucumber extract for $2 \mathrm{~h}$. The total RNAs were isolated by Qiazol reagent (Qiagen Science, USA) according to the manufacturer's protocols. Two micrograms of total RNAs were transcribed using M-MLV reverse transcriptase (Promega, USA), according to the manufacturer's protocols. IL-10 mRNA expression levels were synthesized by real-time PCR using the iCyclerTM (Bio-Rad Laboratories, Hercules, CA, USA). GAPDH was used for the reference gene. IL-10 and GAPDH primer sequence are previously described (Lee et al. 2016).

\section{Statistical analysis}

Statistical analysis was performed by the software SPSS 18.0 with possible differences among diet treatments being tested by using one-way ANOVA. Tukey multiple comparison tests were used to analyze the differences among treatments. Differences were considered significant at a probability level of 0.05 .

\section{Results}

\section{Growth and survival}

The growth performance and survival of sea cucumber are shown in Table 2. All sea cucumbers were alive at the end of the 9-week feeding trial. The growth performance of the sea cucumbers differed significantly among treatments. Final wet and dry body weights of sea cucumbers showed the highest value for the UL diet group and the lowest value for the ST diet group $(P<0.05)$.

The highest SGR $\left(1.58 \% \mathrm{~d}^{-1}\right)$ was observed in sea cucumber fed the UL diet. SGR of sea cucumbers fed the ST diet was significantly $(P<0.05)$ lower than UL, LJ, and NO diets, but not significantly $(P>0.05)$ different from that fed the UP and SS diets (Fig. 1).

\section{Ingestion rate and feces production rate}

Ingestion rates (Fig. 2) and feces production rates (Fig. 3) of the sea cucumbers showed significant differences among different diet treatments. Sea cucumbers fed with diets LJ and UL showed significantly higher IR (0.62 and $0.59 \mathrm{~g} \mathrm{~g}^{-1} \mathrm{~d}^{-1}$ respectively) and FPR (0.53 and $0.52 \mathrm{~g} \mathrm{~g}^{-1}$ $\mathrm{d}^{-1}$ respectively) than those fed other diets $(P<0.05)$. Sea cucumbers fed with diet ST showed the lowest IR $\left(0.32 \mathrm{~g} \mathrm{~g} \mathrm{~g}^{-1} \mathrm{~d}^{-1}\right)(P<0.05)$ and FPR $\left(0.26 \mathrm{~g} \mathrm{~g}^{-1} \mathrm{~d}^{-1}\right)$ $(P<0.05)$ among all treatments.

\section{Food conversion efficiency}

Food conversion efficiency (\%) was significantly different among different diet treatments (Fig. 4). FCE of the sea cucumbers fed with diet NO was $3.74 \%$, which was significantly higher than those fed with other diets $(P<0.05)$. Sea cucumbers fed the diet UP showed the lowest FCE (2.21\%).

\section{Anti-inflammatory cytokine, IL-10 expression level}

In order to establish proper algae for sea cucumber diet, we synthesize IL-10 gene expression levels. Splenocytes were stimulated with each experimental diet-fed sea $\mathrm{cu}$ cumber extract for $2 \mathrm{~h}$. Result showed that IL-10 gene expression levels were significantly increased in the UL, $\mathrm{LJ}$, and NO diets compared to the other experimental diets (Fig. 5). The highest IL-10 gene expression levels were found when the sea cucumbers were fed the Ulva lactuca algae diet. However, IL-10 gene expression levels were not increased by ST, UP, and SS diets and have no significant differences. These results suggest that UL, LJ, and $\mathrm{NO}$ algae could upregulate IL-10 gene expression.

\section{Discussion}

In all treatments, no sea cucumber died and survival rates of sea cucumbers were excellent (100\%) and were

Table 2 Initial and final wet weight (WW) and dry weight (DW) of Apostichopus japonicus fed different test diets (mean \pm SE)

\begin{tabular}{llllll}
\hline Experimental diets & Initial WW $(\mathrm{g})$ & Initial DW $(\mathrm{g})$ & Final WW (g) & Final DW (g) & Survival (\%) \\
\hline ST & $3.04 \pm 0.09$ & 0.28 & $5.07 \pm 0.92$ & 0.47 & 100 \\
UL & $2.93 \pm 0.12$ & 0.27 & $7.65 \pm 0.85$ & 0.71 & 100 \\
UP & $2.94 \pm 0.11$ & 0.27 & $5.94 \pm 0.62$ & 0.55 & 100 \\
LJ & $3.03 \pm 0.07$ & 0.28 & $7.27 \pm 0.45$ & 0.67 & 100 \\
SS & $2.92 \pm 0.10$ & 0.27 & $6.16 \pm 0.15$ & 0.57 & 100 \\
NO & $3.02 \pm 0.06$ & 0.28 & $7.05 \pm 0.18$ & 0.65 & 100 \\
\hline
\end{tabular}




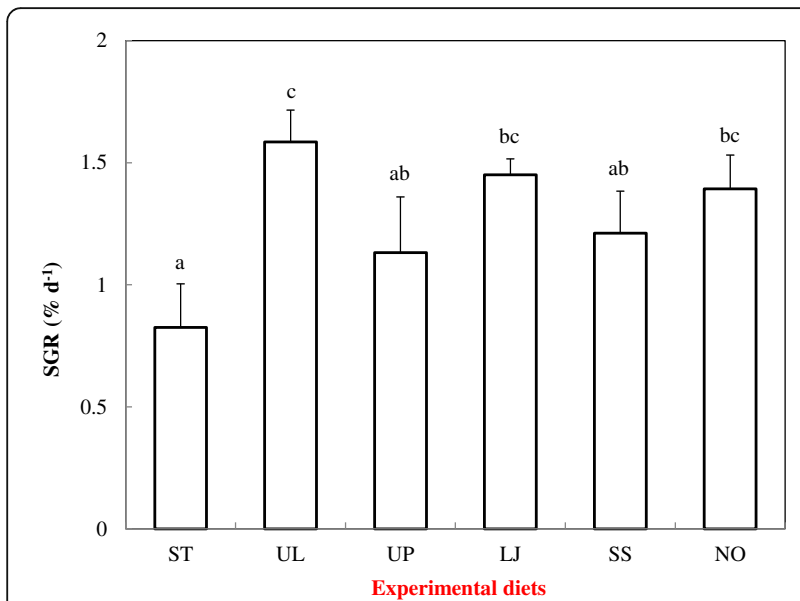

Fig. 1 Specific growth rate of Apostichopus japonicus fed different test diets. Different letters indicate significant differences $(P<0.05)$ between treatments within the same group, and bars represent standard errors

higher than the rates reported in previous similar studies (Hai-Bo et al. 2015; Slater and Carton 2007; Zhou et al. 2006). The results showed that sea cucumbers might have the ability to tolerate the different algae such as UL, UP, LJ, NO, and SS in diet.

Systematic studies on the use of algae as an ingredient in commercial feeds for sea cucumber culture are very rare. Many researchers have used different types of algae such as Sargassum polycystum, Sargassum thunbergii, Laminaria japonica, Spirulina platensis, Ulva lactuca, Undaria pinnatifida, and Pyropia spheroplasts to study sea cucumber nutrition requirements (Li et al. 2009; Liu et al. 2009; Seo and Lee 2011; Seo et al. 2011; Slater et al. 2009; Yuan et al. 2006, Shahabuddin et al. 2017). Most researchers have used $S$. thunbergii as a main feed

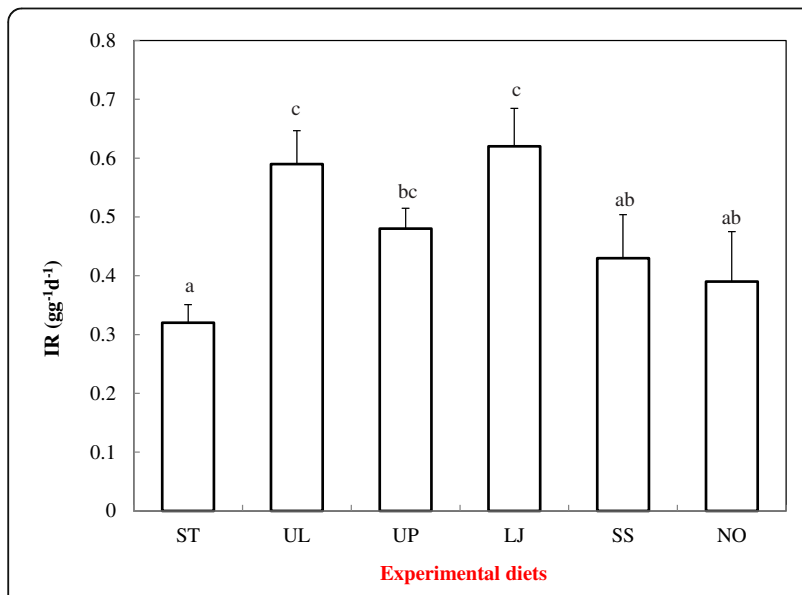

Fig. 2 Ingestion rate (IR) of Apostichopus japonicus fed different test diets. Different letters indicate significant differences $(P<0.05)$ between treatments within the same group, and bars represent standard errors

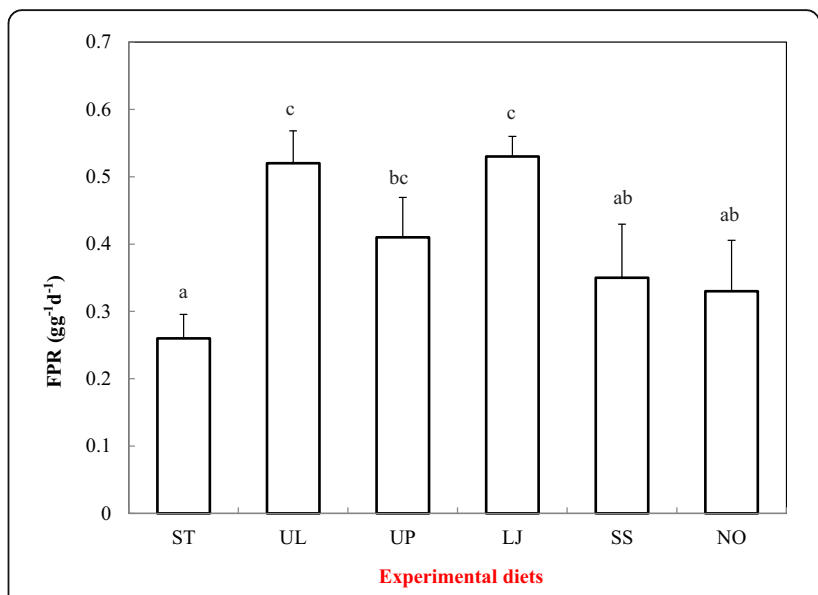

Fig. 3 Feces production rate (FPR) of Apostichopus japonicus fed different test diets. Different letters indicate significant differences $(P<0.05)$ between treatments within the same group, and bars represent standard errors

ingredient in land-based intensive culture systems (Battaglene et al. 1999; Slater et al. 2009). However, in our study of various experimental diets, the SGR was much higher in sea cucumbers fed UL, LJ, or NO diets compared to UP, SS, and ST diets (Fig. 1). Seo et al. (2011) reported that sea cucumbers fed 20\% L. japonica and $20 \%$ S. thunbergii containing diet grew much better than those only eating $S$. thunbergii (40\%) diet. Zhu et al. (2007) also reported that the SGR was increased significantly when sea cucumbers were fed $U$. lactuca compared with S. thunbergii and the SGR of sea cucumbers decreased when they were fed L. japonica. They used much smaller sized $(0.49 \mathrm{~g})$ sea cucumbers compared to ours $(2.98 \mathrm{~g})$. Different size of sea cucumber may have different diet choice and nutrition requirement (Yanagisawa 1998).

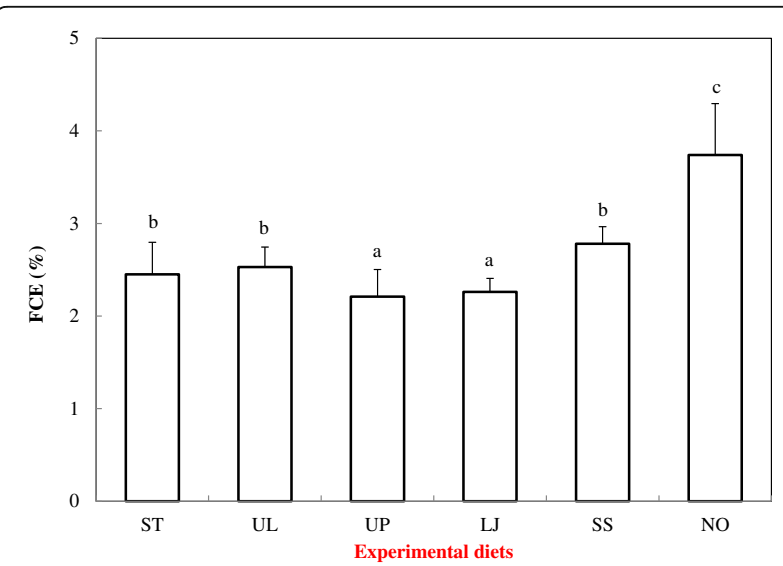

Fig. 4 Food conversion efficiency (FCE) of Apostichopus japonicus fed different test diets. Different letters indicate significant differences $(P<0.05)$ between treatments within the same group, and bars represent standard errors 


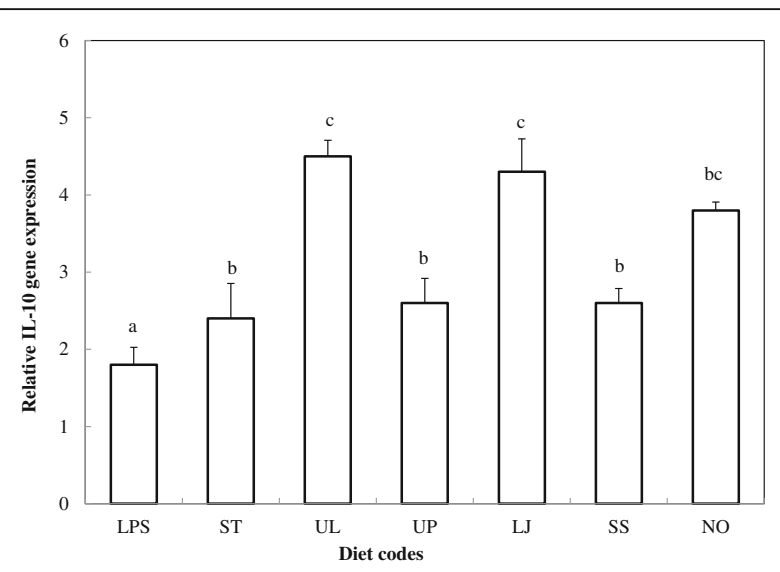

Fig. 5 IL-10 gene expression. IL-10 gene expressions were significantly increased by administration of the $U L, L$, and NO diets

Algae are an important food source for sea cucumbers. Zhu et al. (2007) reported that $U$. lactuca as a feed ingredient for the sea cucumbers was better than $S$. thunbergii in growth performance. In the present studies, NO, ST, SS, and UP diets of which the protein contents were higher than those of the UL and LJ diets were selected to test the effects on growth of the sea cucumbers (Table 2). The results showed that SGR of the sea cucumbers fed the UL and LJ diets was significantly higher than that of those fed the ST, SS, and UP diets. The results indicate that some other factors were responsible for the nutrient effects of the algae besides the protein, lipid, and energy contents. One of the three mechanisms such as acid hydrolysis, enzymatic digestion, or mechanical trituration is necessary to break the cell wall of microalgal cell contents (Bitterlich 1985). For instance, many fishes like tilapia are the species which rely on acid hydrolysis. They are able to disrupt cyanobacterium cell walls because of low $\mathrm{pH}$ values of their stomach fluid (Caulton 1976; Payne 1978). But for holothurians like the sea cucumber, the structure and environment of the digestive tract of the sea cucumber are quite different from tilapia. Sea cucumbers have no specialized organ for grinding or gland for chemical digestion (Massin 1982), and digestive enzyme activities are very low and have very little cellulose activity (Wang et al. 2007). Therefore, sea cucumbers are able to assimilate a specific amount of cellulose content.

In our studies, the higher SGR of the sea cucumber was observed in the treatments fed with the UL and LJ diets though the protein and lipid contents of those diets were comparatively low $(P<0.05)$. UL algae are two cells thick, soft and translucent, and LJ is multicellular, filamentous. Their cell walls are easy to break and have comparatively lower cellulose content (Burrows 1991; Miyai et al. 2008). So, sea cucumbers could easily digest and take full advantage of the nutrients in the UL and LJ algae.
The algae UP and SS contain a significant amount of cellulose and need specific enzyme activities to break the cellulose content (Jurkovic et al. 1995). Sea cucumbers have lower specific enzyme activities and may not digest macroalgae such as SS and UP efficiently (Wang et al. 2007). Moreover, Schizochytrium algae have a higher amount of lipids (Menghe et al. 2009). But sea cucumbers have low tolerance to lipids and do not require a high dietary lipid (Seo and Lee 2011). Therefore, in our studies, sea cucumbers fed the UP and SS diets had lower SGR among all the treatments with the exception of the ST diets.

Ingestion rates (IRs) of sea cucumbers were significantly affected by different experimental diets. There was a negative relationship between IR and the protein level. In the natural ecosystem, low nutritional value of sediment consumed by deposit feeders means those animals need to consume large amounts of sediment in order to obtain a net input of energy (Santos et al. 1994; Hudson et al. 2004). Vice versa, when food quality becomes better, internal appetite regulation would work actively to decrease food ingestion. In this study, the ingestion rate of sea cucumbers decreased when the protein content of the diets increased. The same phenomenon was also found in other echinoderms. McBride et al. (1998) reported that for sea urchin (Strongylocentrotus franciscanus), prepared diets of different protein levels resulted in different ingestion rate. Otero-Villanueva et al. (2004) also found in Psammechinus miliaris that the lowest ingestion rate was related to a high energetic diet.

Regulatory T cells (Treg cells), known as suppressor T cells, are a subpopulation of $\mathrm{T}$ cells and modulate the immune systems (Kikodze et al. 2016). IL-10 is one of the Treg cells and known as a key regulator of immunity to many infections or inflammatory diseases (GutierrezMurgas et al. 2016). For instance, high levels of IL-10 have protective effect against asthma disease (Raeiszadeh Jahromi et al. 2014). Conversely, lack of IL-10 promotes cell apoptosis during virus infection in the small intestine (Pan et al. 2014). In a previous study, we already investigated that administration of sea cumber total extract can upregulate IL-10 and ameliorate asthma disease (Lee et al. 2016). Here, we suggest that UL, LJ, and $\mathrm{NO}$ algae increase interleukin (IL)-10 gene expression.

\section{Conclusions}

In conclusion, the results of this experiment suggest that dietary inclusion with Ulva lactuca, Laminaria japonica, and Nannochloropsis oculata algae may improve growth of juvenile sea cucumbers and could upregulate IL-10 gene expression. Such detailed information could be helpful in further development of more appropriate diets for the culture of sea cucumber. 


\section{Abbreviations}

FCE: Food conversion efficiency; FPR: Feces production rate; IL: Interleukin; IR: Ingestion rate; SGR: Specific growth rate; SR: Survival rate

\section{Acknowledgements}

This research was a part of the project titled "Feed development for the production of sea cucumber contains a substance improving asthma ameliorated material" funded by the Ministry of Oceans and Fisheries, Korea.

\section{Funding}

The design of the study; collection, analysis, and interpretation of the data; and writing of the manuscript were funded by a grant from the Ministry of Oceans and Fisheries, Korea (20150297).

\section{Availability of data and materials}

All datasets generated during and/or analyzed during the current study are available from the corresponding author on reasonable request.

\section{Authors' contributions}

AM, UCJ, and SJK designed the study. AM wrote the article. AM, UCJ, FJ, JKC, and KK manufactured the experimental feed, conducted the feeding trial, and performed the analyses. DIL and HSY performed the interleukin-10 experiment. SJK conceived, coordinated, and revised the manuscript. All authors read and approved the final manuscript.

\section{Ethics approva}

All experimental protocols followed the guidelines of the Institutional Anima Care and Use Committee of the Pusan National University and Gyeongsang National University.

\section{Consent for publication}

Not applicable

\section{Competing interests}

The authors declare that they have no competing interests.

\section{Publisher's Note}

Springer Nature remains neutral with regard to jurisdictional claims in published maps and institutional affiliations.

\section{Author details}

'Department of Seafood and Aquaculture Science, Gyeongsang National University, Tongyeong 53064, Republic of Korea. ${ }^{2}$ Department of Parasitology, School of Medicine, Pusan National University, Yangsan-si, Gyeongsangnam-do 626-870, Republic of Korea.

\section{Received: 16 June 2017 Accepted: 11 September 2017}

\section{Published online: 05 October 2017}

\section{References}

Agatsuma Y. Food consumption and growth of the juvenile sea urchin Strongylocentrotus intermedius. Fish Sci. 2000;66:467-72.

Battaglene SC, Seymour EJ, Ramofafia C. Survival and growth of cultured juvenile sea cucumbers Holothuria scabra. Aquaculture. 1999:178:293-322.

Bitterlich G. Digestive process in silver carp Hypophthalmichthys molitrix studied in vitro. Aquaculture 1985:50:123-31.

Bordbar S, Anwar F, Saari N. High-value components and bioactives from sea cucumbers for functional foods: a review. Marine Drugs. 2011:9:1761-805.

Burrows EM. Seaweeds of the British Isles, vol. 2. London: Natural History Museum; 1991.

Caulton MS. The importance of pre-digestive food preparation to Tilapia rendalli Boulanger when feeding on aquatic macrophytes. Trans Rhod Sci Assoc 1976;57:22-8.

Conand C. Present status of world sea cucumber resources and utilization: an international overview. Advances in sea cucumber aquaculture and management (Lovatelli, A., Conand,C., Purcell, S., Uthicke, S., Hamel, J.F. \& Mercier, A. eds), FAO, Rome, Italy; 2004. p.13-23.

Esmat AY, Said MM, Soliman AA, El-Masry KS, Badiea EA. Bioactive compounds, antioxidant potential, and hepatoprotective activity of sea cucumber (Holothuria atra) against thioacetamide intoxication in rats. Nutrition. 2013;29:258-67.
Farshadpour F, Gharibi S, Taherzadeh M, Amirinejad R, Taherkhani R, Habibian A, Zandi K. Antiviral activity of Holothuria sp. a sea cucumber against herpes simplex virus type 1 (HSV-1). Eur Rev Med Pharmacol Sci. 2014;18:333-7.

Feng J, Jong-Kuk C, U-Cheol J, Anisuzzaman M, Chung-Ho R, Byeong-dae C, Seok-Joong K. Effects of fermented fecal solid diets on growth of the sea cucumber Apostichopus japonicus. Korean J Fish Aqua Sci. 2016b;49:161-7.

Feng J, Anisuzzaman M, U-Cheol J, Jong-Kuk C, Hak-Sun Y, Seung-Wan K, SeokJoong K. Comparison of fatty acid composition of wild and cultured sea cucumber Apostichopus japonicus. Korean J Fish Aqua Sci. 2016a;49:474-85.

Guo Y, Ding Y, Xu F, Liu B, Kou Z, Xiao W, Zhu J. Systems pharmacology-based drug discovery for marine resources: an example using sea cucumber (holothurians). J Ethnopharmacol. 2015;165:61-72.

Gutierrez-Murgas YM, Gwenn S, Danielle R, Matthew B, Jessica N. IL-10 plays an important role in the control of inflammation but not in the bacterial burden in S. epidermidis CNS catheter infection. J Neuroinflammation. 2016:13(1):271.

Hai-Bo Y, Qin-Feng G, Shuang-Lin D, Bin W. Changes in fatty acid profiles of sea cucumber Apostichopus japonicus (Selenka) induced by terrestrial plants in diets. Aquaculture. 2015;442:119-24.

Hudson IR, Wigham BD, Tyler PA. The feeding behavior of a deep-sea holothurian, Stichopus tremulus (Gunnerus) based on in situ observation and experiments using a remotely operated vehicle. J Exp Mar Biol Ecol. 2004;301:75-91.

Jurkovic N, Kolb N, Colic I. Nutritive value of marine algae Laminaria japonica and Undaria pinnatifida. Mol Nutr Food Res. 1995;39:63-6.

Kandilian R, Lee E, Pilon L. Radiation and optical properties of Nannochloropsis oculata grown under different irradiances and spectra. Bioresour Technol. 2013;137:63-73

Kiani N, Heidari B, Rassa M, Kadkhodazadeh M, Heidari B. Antibacterial activity of the body wall extracts of sea cucumber (Invertebrata; Echinodermata) on infectious oral streptococci. J Bas Clin Physiol Pharmacol. 2014;1:1-7.

Kikodze N, Pantsulaia I, Chikovani T. The role of T regulatory and Th17 cells in the pathogenesis of rheumatoid arthritis (review). Georgian Med News. 2016;261:62-8

Lee DI, Park MK, Kang SA, Choi JH, Kang SJ, Lee JY, Yu HS. Preventive intra oral treatment of sea cucumber ameliorate OVA-induced allergic airway inflammation. Am J Chin Med. 2016:44:1663-74.

Li Y, Wang Y, Wang P. Habitat environment and water area selection of stock increment of Apostichopus japonicus. Trans Oceano Limno. 1994:4:42-7.

Li B, Zhu W, Feng Z, Li L, Hu Y. Affection of diet phospholipid content on growth and body composition of sea cucumber, Apostichopus japonicus. Mar Sci. 2009;33:25-8

Liao. Fauna Sinica: Phylum Echiondermta Class Holthuroidea. Beijing: Science Press; 1997. p. 21-37.

Liu Y, Dong S, Tian X, Wang F, Gao Q. Effects of dietary sea mud and yellow soil on growth and energy budget of the sea cucumber Apostichopus japonicus (Selenka). Aquaculture. 2009;286:266-70.

Liu Y, Dong SL, Tian XL, Wang F, Gao QF. The effect of different macroalgae on the growth of sea cucumbers (Apostichopus japonicus Selenka). Aquac Res. 2010:2:1-5

Lobban CS, Harrison PJ. Seaweed ecology and physiology. New York: Cambridge University Press; 1994

Massin C. Food and feeding mechanisms: Holothuroidea. In: Lawrence JM, editor. Echinoderm Jangoux, M. Rotterdam: A. A. Balkema Publishers; 1982. p. 115-20.

McBride SC, Lawrence JM, Lawrence AL, Mulligan TJ. The effects of protein concentration in prepared diets on growth, feeding rate, total organic absorption, and gross assimilation efficiency of the sea urchin Strongylocentrotus franciscanus. J Shellfish Res. 1998:17:1562-70.

Menghe HL, Edwin HR, Craig ST, Lester K. Effects of dried algae Schizochytrium sp. , a rich source of docosahexaenoic acid, on growth, fatty acid composition, and sensory quality of channel catfish Ictalurus punctatus. Aquaculture. 2009; 292:232-6.

Miyai K, Tokushige T, Kondo M. Suppression of thyroid function during ingestion of seaweed "Kombu" (Laminaria japonoca) in normal Japanese adults. Endocr J. 2008:55:1103-8.

Moriarty DJW. Feeding of Holothuria atra and Stichopus chloronotus on bacteria, organic carbon and organic nitrogen in sediments of the Great Barrier Reef. Aus J Mar Fresh Res. 1982;33:255-63.

Otero-Villanueva MM, Kelly MS, Burnell G. How diets influence energy partitioning in the regular echinoid Psammechinus miliaris; constructing an energy budget. J Exp Mar Biol Ecol. 2004;304:159-81.

Pan D, Kenway-Lynch CS, Lala W, Veazey RS, Lackner AA, Das A, Pahar B. Lack of interleukin-10-mediated anti-inflammatory signals and upregulated interferon gamma production are linked to increased intestinal epithelial cell apoptosis 
in pathogenic simian immunodeficiency virus infection. J Virol. 2014;88: 13015-28.

Payne Al. Gut pH and digestive strategies in estuarine grey mullet Mugilidae and tilapia Cichlidae. J Fish Res Board Can. 1978;13:627-9.

Qi ZH, Liu HM, Li B, Mao YZ, Jiang ZJ, Zhang JH, Fang JG. Suitability of two seaweeds, Gracilaria lemaneiformis and Sargassum pallidum, as feed for the abalone Haliotis discus hannai ino. Aquaculture. 2010;300:189-93.

Raeiszadeh Jahromi S, Mahesh PA, Jayaraj BS, Madhunapantula SR, Holla AD, Vishweswaraiah S, Ramachandra NB. Serum levels of IL-10, IL-17F and IL-33 in patients with asthma: a case-control study. J Asthma. 2014;51:1004-13.

Santos V, Billett DSM, Rice AL, Wolff GA. Organic matter in deep-sea sediments from the porcupine abyssal plain in the north-east Atlantic Ocean: 1. Lipids. Deep-Sea Res. 1994;41:789-819.

Seo JY, Lee SM. Optimum dietary protein and lipid levels for growth of juvenile sea cucumber Apostichopus japonicaus. Aquac Nutr. 2011;17:56-61.

Seo JY, Shin IS, Lee SM. Effect of dietary inclusion of various plant ingredients as an alternative for Sargassum thunbergii on growth and body composition of juvenile sea cucumber Apostichopus japonicaus. Aquac Nutr. 2011;17:549-56. Shahabuddin AM, Khan NMD, Koji M, Araki T, Yoshimatsu T. Dietary supplementation of red alga Pyropia spheroplasts on growth, feed utilization and body composition of sea cucumber, Apostichopus japonicus (Selenka). Aquac Res. 2017:1:1-10.

Shi C, Dong SL, Pei SR, Wang F, Tian XL, Gao QF. Effects of diatom concentrationin prepared feeds on growth and energy budget of the sea cucumber Apostichopus japonicus (Selenka). Aquac Res. 2013;46:609-17.

Slater MJ, Carton AG. Survivorship and growth of the sea cucumber Australostichopus (Stichopus) mollis (Hutton 1872) in polyculture trials with green-lipped mussel farms. Aquaculture. 2007;272:389-98.

Slater MJ, Je AG, Carton AG. The use of the waste from green-lipped mussels as a food source for juvenile sea cucumber, Australostichopus mollis. Aquaculture. 2009;292: 219-24.

Sloan NA. Echinorderm fisheries of the world: a review. Echinodermata (Proceedings of the Fifth International Echinoderm Conference). Rotterdam: A. A. Balkema Publishers; 1984. p. 109-24

Sui $X$. The main factors influencing the larval development and survival rate of the sea cucumber Apostichopus japonicus. Oceanolo et Limnolo Sinica. 1989;20:314-21.

Wang FJ, Sun XT, Li F. Studies on sexual reproduction and seedling-rearing of Sargassum thunbergii. Mar Fish Res. 2006;27:1-6.

Wang JQ, Tang L, Xu C, Cheng JC. Histological observation of alimentary tract and annual changes of four digestive enzymes in sea cucumber (Apostichopus japonicus). Fish Sci. 2007;26:481-4.

Wijesinghe WA, Jeon YJ, Ramasamy P, Wahid ME, Vairappan CS. Anticancer activity and mediation of apoptosis in human HL-60 leukaemia cells by edible sea cucumber (Holothuria edulis) extract. Food Chem. 2013;139:326-31.

Yanagisawa T. Aspects of the biology and culture of the sea cucumber. In: De Silva S, editor. Tropical Mariculture. London: Academic; 1998. p. 291-308.

Yingst JY. The utilization of organic matter in shallow marine sediments by an epibenthic deposit-feeding holothurian. J Exp Mar Biol Ecol. 1976;23:55-69.

Yuan CY. Current status and development of feed in sea cucumber. Fish Sci. 2005;24:54-6.

Yuan X, Yang H, Zhou Y, Mao Y, Zhang T, Liu Y. The influence of diets containing dried bivalve feces and/or powdered algae on growth and energy distribution in sea cucumber Apostichopus japonicus (Selenka) (Echinodermata: Holothuroidea). Aquaculture. 2006;256:457-67.

Yue J, King-Wai F, Raymond TYW, Feng C. Fatty acid composition and squalene content of the marine microalga Schizochytrium mangrovei. J Agri Food Chem. 2004:52:1196-200.

Zhang BL, Sun DL, Wu YQ. Preliminary analysis on the feeding habit of Apostichopus japonicus in the rocky coast waters off Lingshan Island. Mar Sci. 1995;3:11-3.

Zhou Y, Yang H, Liu S, Yuan X, Mao Y, Zhang T, Liu Y, Zhang F. Feeding on biodeposits of bivalves by the sea cucumber Stichopus japonicus Selenka (Echinidermata: Holothuroidea) and a suspension coculture of filter-feeding bivalves with deposit feeders in lantern nets from longlines. Aquaculture. 2006;256:510-20.

Zhu J, Liu H, Leng K, Qu K, Wang S, Xue Z, Sun Y. Studies on the effects of some common diets on the growth of Apostichopus japonicaus. Mar Fish Res. 2007;25:48-53.

\section{Submit your next manuscript to BioMed Central and we will help you at every step:}

- We accept pre-submission inquiries

- Our selector tool helps you to find the most relevant journal

- We provide round the clock customer support

- Convenient online submission

- Thorough peer review

- Inclusion in PubMed and all major indexing services

- Maximum visibility for your research

Submit your manuscript at www.biomedcentral.com/submit
Biomed Central 